CBJM 13600092 Initial $\quad$ CE: ER QA: XX

\title{
Islamizing the Palestinian-Israeli conflict: the case of the Muslim Brotherhood
}

\author{
Noha Mellor

\section{ABSTRACT}

The Arab capitulation in the Six Day War was posited to stimulate the so-called Islamic resurgence in the region since the 1970s, which several scholars see as a sign of Islamic resistance to the Western cultural presence within the Arab world. This article argues that Islamizing the conflict began well before the 1967 defeat, and that the hegemony of the Islamist discourse has been made possible owing to its penetration into mainstream political and media discourses. It is also argued that by 'religionizing' the Palestinian-Israeli conflict, Islamists provide a new narrative to reshape and reframe the perception of this conflict as being religious rather than political in nature. The article takes the Muslim Brotherhood as a topical case study, demonstrating how its print and digital media highlighted the Islamization of the conflict with Israel and providing frequent references to the 1967 defeat as evidence of God's wrath meted out on Arab rulers, not only for abandoning the Islamic State project, but also for oppressing Islamist movements.

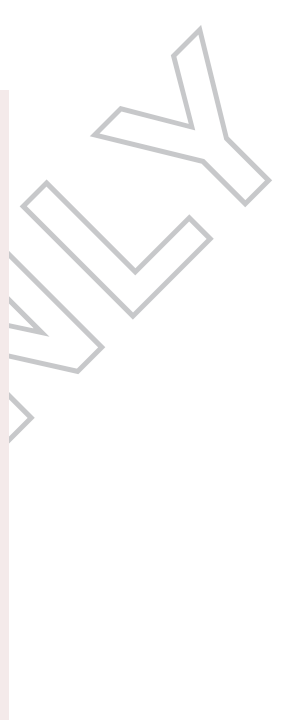

Commemorating the 10th anniversary of the 1967 Israeli conquest, the Muslim Brotherhood (MB)'s magazine al-Dawa, provided an 'Islamic perspective' in its analysis of the defeat. This defeat was regarded as the natural consequence of driving out Islamist movements, 'Islam could not join the war, because it was banished behind bars as part of the intentional Zionist plan to imprison the Islamic movement before Israel could wage any attack'. The defeat, as argued in subsequent issues, was said to have provided the pretext for the Jews to destroy the Aqsa Mosque; indeed, the official statements by the Brotherhood, and up until their accession to power in 2012, affirmed their view of the Palestine issue as an Islamic issue par excellence and not a political conflict, thereby viewing it solely from a religious perspective.

The Arab capitulation in the Six Day War was posited to stimulate the so-called Islamic resurgence in the region since the 1970 s, which several scholars ${ }^{2}$ see as a sign of Islamic resistance to the Western cultural presence within the Arab world. If modernization spurs

CONTACT Noha Mellor noha.mellor@beds.ac.uk

${ }^{1}$ Al-Dawa, June 1977.

${ }^{2}$ See e.g., Youssef M Choueiri, 'The political discourse of contemporary Islamist movements', in Abdel Salam Sidahmed and Anounshirvan Ehteshami (eds), Islamic Fundamentalism (Boulder:Westview, 1996); John Esposito, Islam and Secularism in the Middle East (London: Hurst \& Company, 2000). 


\begin{tabular}{|c|c|c|}
\hline $\begin{array}{l}\text { CBJM } 1360009 \\
2 \text { August } 2017\end{array}$ & Initial & $\begin{array}{ll}\text { CE: ER } & \text { QA: XX } \\
\text { Coll:XX } & \text { QC:XX }\end{array}$ \\
\hline
\end{tabular}

nostalgia for the past as a direct reaction to the rapid modern social changes, it also gives rise to religious resurgence such as the so-called re-Islamization of the Arab world and other Muslim countries. However, rising Islamism not only posed a threat to the existing Arab rulers but also 'Islamized' the Palestinian-Israeli conflict. That conflict began as a rivalry between two national movements, namely, Zionism and Palestinian nationalism, but, following the 1936 Arab revolt, it became a conflict that several Arab states that had gained independence in the 1950s regarded as a Western ploy to weaken pan-Arab nationalism. ${ }^{3}$ The Islamization of the conflict, however, 'entails several consequences: a certain conceptualization of the conflict's causes and sources through religious-Islamic lenses; a perception of the desirable solution; and the provision of the motivation and justification for a specific mode of conduct in order to achieve that goal', as Litvak argues. This perception of the conflict therefore becomes'a battle between two rival religions, Islam and Judaism, or between two opposing absolutes. ${ }^{4}$

Yvonne Haddad, ${ }^{5}$ on the other hand, posits that the Islamist ideology 'was not created by the war, but the latter's outcome provided a framework for projecting and explaining a perception that seemed to be validated by subsequent policies of the United States and Israel'. There was, indeed, a tendency to call for 'renewal of faith' in the wake of the defeat, which could be regarded as a natural reaction, especially as Nasser himself referred to it as a reminder from God to Muslims to 'purify their souls.' Resorting to faith was not just confined to Muslims; in fact, in May 1968, Pope Cyril VI of Alexandria announced the apparition of the Virgin Mary on top of St Mark's Coptic Church in the neighbourhood of Zeitoun. Nasser's government used that occasion to raise people's morale by suggesting that the apparition was a sign from God of an imminent victory, because 'Saints and martyrs only appear in times of crisis to support [the people]'? Muslim nations such as Turkey, Iran and Pakistan shared similar sentiments during the Islamic Congress in Mecca in October 1967, referring to the war as a'Zionist aggression against the Holy Shrines', although there was 'no outbreak of religious tension or persecution'in either Syria or Egypt immediately after the war. ${ }^{8}$ The Islamists projected the defeat as a divine punishment for trusting foreign ideologies such as Socialism, as the basis for modernization. ${ }^{9}$ The respected Sheikh Shaarawi (d. 1998), whose widespread popularity earned him the title of 'Preacher of the century', revealed that he had personally prayed to God in gratitude for the defeat, because it obliterated Egyptian Socialism (referring to the Nasserite regime), which he regarded as atheistic. ${ }^{10}$

In this article, (argue that Islamizing the conflict began well before the 1967 defeat, and that the hegemony of the Islamist discourse has been made possible owing to its penetration 35 into mainstream political and media discourses. I also contend that, by 'religionizing' the conflict, Islamists provide a new narrative to reshape and reframe the perception of this

\footnotetext{
${ }^{3}$ Meir Litvak, The Islamization of the Palestinian-Israeli Conflict: The Case of Hamas. Middle Eastern Studies, Vol. 34(1), 1998, $148-163$, p. 148

${ }^{4}$ Litvak, 1998, 148

${ }^{5}$ Yvonne Haddad, Islamists and the 'Problem of Israel': The 1967 Awakening. Middle East Journal, Vol. 46 (2), Spring, 1992: $266-285$, p. 266

${ }^{6}$ L. M. Kenny, the Aftermath of Defeat in Egypt. International Journal, Vol. 23, No. 1: 97-108 (Winter, 1969), pp. $105-106$.

${ }^{S}$ adeq Jalal Al-Azm, Naqd al-Khitab al-Deeni. 2nd edition (Beirut: Dar al-Talia, 1970), p. 176.

${ }^{8}$ Kenny, 1969, 105-106.

${ }^{9}$ Haddad, 1992, 267.

${ }^{10}$ Nasr Hamid Abu Zeid, Naqd el Khitab el-Deeni (Cairo: Sina Publishing, 1994), pp. 71-72.
} 


\begin{tabular}{|lcc|}
\hline CBJM 1360009 & \multirow{2}{*}{ Initial } & CE: ER QA: XX \\
2 August 2017 & Coll:XX & QC:XX \\
\hline
\end{tabular}

conflict as being religious rather than political in nature. The article takes the Muslim Brotherhood (MB) as a topical case study, demonstrating how its print and digital media highlighted the Islamization of the conflict with Israel, providing frequent references to the 1967 defeat as evidence of God's wrath meted out on Arab rulers, not only for abandoning the Islamic State project, but also for oppressing Islamist movements. The article focuses on the Egyptian face of this movement, which later branched out into different countries across the world, and on selected examples from its print and digital media to reach out to the general public, both inside and outside Egypt, while enforcing the MB's position vis-à-vis the political establishment. ${ }^{11}$ The MB media formed a communicative platform to disseminate their values; analysing their media messages can help to understand the development of the Islamization of the narratives, particularly with regard to the Palestinian-Israeli conflict. The MB's founder, Hasan al-Banna (1906-1949), realized the power of the written word in reaching out to larger audiences, and this is perhaps why the movement 'turned journalism into a major agency with overriding Islamic goals.' ${ }^{12}$ The movement's publications were gen-

15 erally a useful tool for rebutting accusations levied at the MB, mobilizing supporters, voicing the MB's response to governmental policies and providing a platform to explain the MB's own decisions. The Brotherhood's publications were commonly occupied by providing views rather than news. Contributors to those magazines were mainly members and supporters, in addition to the General Guides; consequently, their ethical and religious capital was far more important than their professional journalistic skills.

The following sections elaborate on the role of religious narrative and religious nationalism as the bedrock for shifting the public perception of the Palestine issue, thereby rendering rather superfluous the political negotiations; examples from the MB publications illustrate how they have Islamized this political conflict.

\section{Religious narrative}

Roberto Franzosi ${ }^{13}$ explores the importance of narrative in social analysis, and how the analysis of linguistic features can guide our understanding of narrative stories. These features, for example, could include the scrutiny of characters, following Propp's classification of the roles of villain, donor, helper, dispatcher, sought-for person, hero and false hero. This narrative

30 analysis is 'linked to a wealth of background knowledge that readers consciously or unconsciously bring to the text in the construction of meaning. ${ }^{14}$ It is 'through narratives that we come to know, understand and make sense of the social world, and it is through narratives and narrativity that we constitute our social identities'15; thus, everything we do 'from making families, to coping with illness, to carrying out strikes and revolutions is at least in part a 35 result of numerous cross-cutting relational story-lines in which social actors find or locate themselves.' ${ }^{16}$ This type of narrative includes several features such as relationality of its parts,

\footnotetext{
${ }^{11}$ For a detailed discussion of the MB media, see Noha Mellor, Voice of the Muslim Brotherhood (New York: Routledge, 2017). ${ }^{12}$ Uri M Kupferschmidt, Literacy, Illiteracy and Censorship in the Tradition of the Muslim Brotherhood, in Philip Sadgrove (ed.) Printing and Publishing in the Middle East. Journal of Semitic Studies, Supplement 24 (Oxford: Oxford University Press, 2008): $165-184$, p. 170.

${ }^{13}$ Roberto Franzosi, Narrative Analysis — or Why (and How) Sociologists Should be Interested in Narrative. Annual Review of Sociology, Vol. 24: 517-554, 1998, pp. 523-524.

${ }^{14}$ Franzosi, 1998, 545 .

${ }^{15}$ Margaret R. Somers, The narrative constitution of identity: A relational and network approach. Theory and Society, Vol. 23: 605-649, 1994, p. 606.

${ }^{16}$ Somers, 1994, 607
} 


\begin{tabular}{|c|c|c|}
\hline $\begin{array}{l}\text { CBJM } 1360009 \\
2 \text { August } 2017\end{array}$ & Initial & $\begin{array}{ll}\text { CE: ER } & \text { QA: XX } \\
\text { Coll:XX } & \text { QC:XX }\end{array}$ \\
\hline
\end{tabular}

causal emplotment, selective appropriation and temporality. ${ }^{17}$ Narratives are thus 'packed with sociological information'; the story can include an initial state, and then disruption, followed by a new state and a final equilibrium, or before and after moments. ${ }^{18}$

The Islamist narrative of cultural incursion and the threat to erode Islam can be classified as a 'public narrative', or one that is attached to cultural formation and not merely to one single individual. ${ }^{19}$ Central to this new narrative are the religious texts (particularly the Qur'an and Hadith) as the only legitimate source on which to draw, in order to conceptualize political conflicts. The narrative draws on a story and a plot or the 'skeletal description of the fundamental events' versus the arranged and connected events in the story as presented to the 10 reader. ${ }^{20}$ This narrative has become so hegemonic that it has been adopted by both mainstream regimes and mainstream media.

There are indeed certain discourses that can dominate the political sphere and become hegemonic through the process of 'recontextualization' or'the appropriation of elements of one social practice within another, placing the former within the context of the latter, and

15 transforming it in particular ways in the process ${ }^{21}$; where a hegemonic discourse proliferates, different domains and 'different social actors will represent them differently according to how they are positioned within the practice.22 The political field, as the most powerful field in society, is a battle in which diverse groups struggle to change power (im)balances and strive for hegemony. This desire for supremacy also encompasses discursive hegemony, or

20 a selected construction and definition of reality, which, in itself, is an interactive process ${ }^{23}$; consequently, each group within the political field strives tolegitimize its argument regarding 'truth' by using a set of discursive practices. This discursive process draws on intertextuality and interdiscursivity. ${ }^{24}$ Intertextuality refers to the way texts are linked to each other in order to arouse attention and interest. Interdiscursivity, which is closely connected to intertextuality, ${ }^{25}$ refers to the way different discourses and genres merge within a communicative event, such as the use of extracts from the Qur'an and Hadith in political speeches or media articles. This process of intervention, argues Fairclough, ${ }^{26}$ not only is the transfer of a discourse into a new domain but also signifies a new means of appropriating and re-contextualizing this discourse.The regime, for instance, can draw on religious educational discourse to garner mass support among Islamists, thereby attributing specific norms and values to the education field. ${ }^{27}$ Islamic discourse can likewise be used to appropriate a political discourse, such as the Palestinian-Israeli conflict, through the lens of specific religious texts, thus limiting the potential for negotiation and reconciliation to solve this conflict. If the 1967 defeat provided a political opportunity for Nasser's opponents-particularly the

\footnotetext{
${ }^{17}$ Somers, 1994, 616

${ }^{18}$ Franzosi, 1998, 519-521.

${ }^{19}$ Somers, 1994, 619

${ }^{20}$ Franzosi, 1998, 519.

${ }^{21}$ Norman Fairclough, Analysing Discourse (London: Routledge, 2003), p. 32

${ }^{22}$ Fairclough, 2003, 215.

${ }^{23}$ Maarten A Hajer, Doing discourse analysis: coalitions, practices, meaning. In: Van den Brink, Margo/Metze, Tamara: Words

Matter in Policy and Planning. Discourse Theory and Method in the Social Sciences (Utrecht: Netherlands Graduate

School of Urban and Regional Research, 2006): 65-76, p. 72.

${ }^{24}$ Fairclough, 2003.

${ }^{25}$ Norman Fairclough, Discourse and Social Change (Cambridge: Polity, 1992).

${ }^{26}$ Fairclough, 1992.

${ }^{27}$ Aziz Talbani, Pedagogy, power and discourse: transformation of Islamic education. Comparative Education Review 40(1), 1996, pp. 66-82.
} 


\begin{tabular}{|lcc|}
\hline $\begin{array}{l}\text { CBJM 136000 } \\
\text { 2 August } 2017\end{array}$ & Initial & CE: ER QA: XX \\
& Coll:XX QC:XX \\
\hline
\end{tabular}

Islamists - to attack Nasserite policies, the dominance of the Islamic discourse has provided an equally powerful discursive opportunity for the Islamists to have their voice heard.

The $M B$, for one, publicized itself as a movement with political demands tightly enmeshed within the religious reforms it sought, which can be summed up in its call to be ruled by Islam and Islamic ethos. Their Islamization of the Palestinian-Israeli conflict has been part of the MB's attempt to propagate its unique sense of nationalism, anchored in Islam and not in territorial nationalism, as will be explained in the following section.

\section{Religious nationalism}

Religion, and particularly Islam, has long been celebrated as the glue that binds the majority of Egyptians to a large, worldwide Islamic community. Religious nationalism is manifested in the relationship between nationalism and Islam, and the way that the state can draw on Islam to rationalize its politics, while social movements and civil society can draw on Islam to substantiate their demands for social change. Religious nationalism then rivals secular nationalism, which was upheld during colonial rule and adopted by the educated elites.

15 Religious nationalism depends on the collective moral values within society, and it may be a reaction to the failure of applying Western models of development. ${ }^{28}$ Religious nationalism, moreover, blurs the borders between the public, religious and private spheres: public and private realms should conform with the religious values and teachings in order to ensure social justice and freedom. ${ }^{29}$ Brubaker $^{30}$ contends that a spiritual or godly nationalism, defined as a religious form of nationalism, does not apply neatly to the Islamic world, because the latter does not form one sovereign nation with clear political legitimacy: each country claims its own representation and resources distinct from the other Islamic nations, even where Islamist movements in each of those countries seek to gain more political power.

During the early part of the twentieth century, Egyptians were navigating between dif-

25 ferent currents of imagining their own national identity: one that glorified Islam as the basis of this identity, and another that glorified Egyptian Pharaonic history. This clearly distinguished Egypt from the rest of the region. The liberal Wafd party, for instance, offered a new vision of Egyptian unity, based on secularist nationalism, but its appeal was rather limited among the Nationalist Party's old guard who had joined the Young Muslim Men's Association

30 (YMMA) in 1927.31 It was also that environment which paved the way for a populist movement - the Muslim Brotherhood - to distinguish itself from the YMMA which'was essentially an urban organization with its roots firmly fixed in the educated classes.32

The Brotherhood offered a new sense of Islamic nationalism based on three aspects, the Egyptian nation, Arabism and Islam, because one, according to the Brotherhood, cannot

35 take preference over the other, for the three are intertwined. Loyalty to Egypt means exalting Egypt's position as the qualified leader of the Arab world, and the unity of Egypt and the

\footnotetext{
${ }^{28}$ Mark Juergensmeyer, The New Cold War? Religious Nationalism Confronts the Secular State (Berkeley: University of California Press, 1993), pp. 194-195.

${ }^{29}$ Ira M. Lapidus, 'Contemporary Islamic movements in historical perspectives', Policy Papers in International Affairs, 18 (Berkeley: University of California, 1983).

${ }^{30}$ Rogers Brubaker, Religion and Nationalism: Four Approaches. Nations and Nationalism, Vol. 18, 2012, Issue 1: 2-20.

${ }^{31}$ Mohamed Aboulkhir Zaki, Modern Muslim Thought in Egypt And Its Impact on Islam in Malaya. Unpublished PhD thesis, University of London, 1965, p. 231.

32Zaki, 1965, 243.
} 


\begin{tabular}{|c|c|c|}
\hline $\begin{array}{l}\text { CBJM } 1360009 \\
2 \text { August } 2017\end{array}$ & Initial & CE: ER QA: XX \\
\hline
\end{tabular}

Arab world would ultimately mean the unity of the Islamic umma. ${ }^{33}$ The Brothers have always declared their belief in Islam as deen wa dawla or a religion and a code for state affairs, and it is this intertwining of Islam and politics that makes it difficult to see the Brotherhood media messages solely through the lens of religious media; its media rather represented a new voice calling for an all-encompassing Islam that would provide the solution to all political and social ills. The MB movement had rapidly expanded during the 20 years of Hasan al-Banna's leadership, but, instead of helping the nationalists in their struggle against the British presence in Egypt, argues Tareq al-Bishri, ${ }^{34}$ the MB ended up diverting the public energy and mood away from those nationalistic goals. The MB sought to renew the Egyptian identity through its Islamization in an attempt to rid Egypt of the influences of Western cultural imperialism.

The 1952 coup drastically changed the political scene in Egypt. It was initially supported by the Brotherhood, whose main concern was to re-open the case of al-Banna's assassination, confident of the army officers' dismay regarding the killing of the MB's founder. Following

15 the alleged MB's foiled attempt to assassinate Nasser in 1954, however, the MB was dissolved and its press confiscated. That period is what the MB defines as mihna or crisis, and it was during that time that members were imprisoned and tortured, and even some were executed under Nasser's rule. The movement could have been completely eroded here, even in the wake of the defeat of the Six Day War, which was a huge blow to Nasser's regime. The political opportunity manifested in Sadat's policy, on the other hand, allowed the Islamist movements to flourish, in an attempt to curb the growing socialist and communist trends, which was instrumental in giving the Brotherhood movement another chance to revive its mission.

There is no doubt that the 1967 defeat damaged Nasser's authority, although it did not totally destroy it. The defeat ignited riots, particularly among students in Mansoura and Alexandria; more than 5,000 students demonstrated in the latter city, and three night clubs were destroyed. The riots in Mansoura were claimed to be the work of the MB because many students came from the Islamic College there, whereas the Alexandrian student body was claimed to be from Marxist ranks. Five universities were closed down in anticipation of more riots, particularly in Cairo.The students in Cairo were furious, following the lenient sentences

30 imposed on military officers held responsible for the defeat..$^{35}$ The defeat prompted Nasser to initiate a series of reforms, such as the re-organization of the Arab Socialist Union and the end of martial law, 36 while mitigating calls for isolation from Western culture. The ensuing protests in the Faculty of Arts in Cairo University demanded the banning of modern American literature from the curriculum. The then minister of education, Tharwat Okasha, condemned

35 the protests by saying, 'Any call for isolation from foreign cultures is a call for petrifaction, which will hurt the vitality and creativity of the people..37

The liberal and leftist intellectuals in particular felt the severe repercussions of the war on the Arab cultural scene. Arab Intellectuals, argues the Egyptian Galal Amin, ${ }^{38}$ contributed to the feeling of humiliation and frustration by writing about the social ills, thereby adding to the prevalent mood of shame and self-hatred. The Syrian Georges Tarabichi regards the

\footnotetext{
${ }^{33}$ Israel Gershoni \& James P. Jankowski, Redefining the Egyptian Nation, 1930-1945 (Cambridge: Cambridge University Press, 2002) pp. 95-96.

${ }^{34}$ Tariq Al-Bishri, Al haraka al siyassiya fi misr (Cairo: Dar al Shorouq, 2002), p. 141

${ }^{35}$ The Times (1968) Threat to Nasser regime grows after riots. November 27, 1968.

${ }^{36}$ Abbas Kelidar, Shifts and Changes in the Arab World. The World Today, Vol. 24, No. 12 (Dec., 1968), pp. 503-511, p. 507.

${ }^{37}$ Cited in Kenny, 1969, 105.

${ }^{38} \mathrm{Galal}$ Amin, al-Muthaqqafun al-Arab wa Israel (Cairo: Dar el Shorouq, 1998).
} 


\begin{tabular}{|lll|}
\hline CBJM 1360009 & Initial & CE: ER QA: XX \\
2 August 2017 & & Coll:XX QC:XX \\
\hline
\end{tabular}

BRITISH JOURNAL OF MIDDLE EASTERN STUDIES

defeat as a mark of the loss of self-esteem in the Arab consciousness, and the loss of confidence in the father of Pan-Arabism, Gamal Abdel Nasser. ${ }^{39}$ There was widespread disbelief that the defeat had actually occurred. This had concluded years of Egyptian overconfidence and high expectations following the nationalization of the Suez Canal and challenging the tripartite attack in 1956; even Egypt's advance in the 1973 war was rather short-lived, with the Egyptian army already talking about a peace treaty a few days after crossing the Bar-Lev line.

Nasser's popularity was still felt in the street, despite the defeat, and his resignation was not accepted by the public perhaps because of the lack of an alternative leadership at the time. ${ }^{40}$ Nasser's death on 28 September 1970 was therefore mourned by millions of Egyptians who took to the street to say their final goodbyes at Nasser's funeral, and they stayed in the street until dawn, including veteran former Brother, Abdel Sattar al-Meligy ${ }^{41}$ as he recalled in his memoirs. Following Nasser's death in 1970, Sadat became the president of Egypt (1970-1981), and he marked his commitment to the Islamic heritage, allegedly suppressed

15 by Nasser. Sadat's politics began with the release of the incarcerated Muslim Brothers to employ the Islamists against the Nasserites and Communists. The latter groups dominated public spaces such as most universities at the time, and it was a battle for the Islamists to seize power from those groups on campuses and syndicates, argues the former Brother, Abul Ela Madi, ${ }^{22}$ founder of al-Wasat Party; even religious spaces such as mosques took some 20 time for the $M B$ and other Islamists to penetrate, given the dominance of state preachers. ${ }^{43}$

The role of religion was nevertheless foregrounded in the political sphere, even during Nasser's era. Nasser attempted to gain the people's support, especially MB sympathizers, and he drew on the Brotherhood's religious rhetoric in his public speeches, in which he

25 likened the political mission of the Free Officers to the Islamic jihad. He distinguished between lesser and greater jihad, where the former finished with the end of colonialism, while the latter referred to the subsequent work in rebuilding the country. ${ }^{44}$ Islamists thus sought to colour their religious discourse with a political hue, whereas politicians sought to coat their political discourse with a religious veneer, including Nasser's predecessors

30 (such as Prime Minister Ali Maher and King Farouq ${ }^{45}$ ). This trend was to continue during subsequent decades with Presidents Nasser, Sadat and Mubarak, drawing on religious discourse to legitimize their policies. It was indeed this vacillation between religious and political discourses that has marked contemporary regional politics for a long time, and the Palestine question clearly demonstrates this increasing intertwining of religious and political discourses.

\footnotetext{
${ }^{39}$ Noha Mellor, The Egyptian Dream. On Egyptian National Identity and the Uprisings (Edinburgh: Edinburgh University Press, 2016), p. 127.

${ }^{40}$ Peter Mansfield, Egypt since June 1967. The World Today, Vol. 24, No. 10 (Oct., 1968), pp. 414-420, p. 414.

${ }^{41} \mathrm{Al}-\mathrm{Sayyed}$ Abdel Sattar Al-Meligy, Tagrabati maa al-ikhwan (Cairo: al-Zahraa lil ilam al-Arabi, 2009).

${ }^{42}$ Abul Ela Madi, Gamaat al-unf al-dawliyya wa ta'welathia lii-Islam (Cairo: Maktabat al-Shurouq, 2006).

${ }^{43}$ Al-Meligy, 2009.

${ }^{44}$ Abu Zeid, 1994, 55.

${ }^{45}$ See, for example, Charles Tripp, Ali Mahir Pasha and the Palace in Egyptian Politics. Unpublished PhD thesis, School of Oriental and African Studies, University of London, 1984.
} 


\begin{tabular}{|c|c|c|}
\hline $\begin{array}{l}\text { CBJM } 1360009 \\
2 \text { August } 2017\end{array}$ & Initial & $\begin{array}{ll}\text { CE: ER } & \text { QA: XX } \\
\text { Coll:XX } & \text { QC:XX }\end{array}$ \\
\hline
\end{tabular}

\section{Hasan al-Banna's project to Islamize politics}

It is important to note that the Palestine question did not occupy most Egyptian politicians in the early part of the twentieth century; in fact, Saad Zaghlol, the celebrated national leader who headed the Egyptian Delegation to the Peace Conference in Paris in 1919, presented the Egyptian demands as pertaining solely to Egypt and not to other Arab countries. He later refused to comment on the situation in Syria and Palestine, as he considered these matters were of little or no concern to him. ${ }^{46}$ Sheikh al-Azhar and Abul Fadl al-Jizawi rejected the appeal to support the Palestine cause in 1929, because it was a political issue, according to them, and calls by both the YMMA and the MB to see this question as an Islamic issue were ignored ${ }^{47}$; nonetheless, both the YMMA and the MB collaboratively campaigned for the Palestinian Arabs, which reached its peak during the Arab Revolt. ${ }^{48}$ Mayer ${ }^{49}$ contends, however, that neither the YMMA nor the MB was a mass organization in 1936, and thus their propagation of the Palestine conflict could not be claimed to have swayed public opinion in Egypt. The late veteran Brother and MB historian, Mahmoud Abdel Halim, ${ }^{50}$ in fact, acknowledged that he only learned about the Palestinian issue when he joined the MB around 1936. He met the Palestinian mufti, Amin al-Hussaini, who visited the MB centre and explained the events as follows:'the British plot which drove naïve Muslim men [in Palestine] to sell their lands to the Jews so as to provide the latter with the opportunity to control the situation in Palestine'. The late Syrian MB leader, Mustafa al-Sibai (d. 1964), had expressed his frustrations with the Egyptians' ignorance of what was happening in Syria and Palestine in one of his articles in al-Fath magazine in 1940, 'We [Syrians] were often asked [by Egyptians] about the geographical location of Syria and the difference between Syria and Lebanon, or who ruled Palestine and Syria, and who the Syrian ruler was. This showed the [little] information some of our Egyptian brothers had [...] and that was the case with the educated [Egyptians], let alone the masses. .51

The Palestinian issue gained more attention after the Arab Revolt in 1936-1939, and the former prime minister, Mustafa al-Nahhas, who had previously dismissed the Palestinian issue as a foreign affair, now sought to promote himself as the chief Arab leader to convince his British allies of Egypt's role as a moderate force in the region..$^{52}$ It was argued during that time that Hasan al-Banna showed admiration for both fascist leaders, Hitler and Mussolini, describing them as 'leaders of modern nahda [renaissance] in Europe', and praised their treaties with the Vatican as an indication that they did not seek to fight religion but really wished to enforce its role in society. ${ }^{53}$

The MB had gained a larger membership by 1938 and had begun to focus on the Palestinian issue to profile itself as a revolutionary movement; in addition to preaching in a

\footnotetext{
${ }^{46} \mathrm{Abd}$ al-Fattah Muhammad El-Awaisi, The Muslim Brothers and The Palestine Question 1936-1947. Unpublished PhD thesis, University of Exeter, 1986, p. 43.

${ }^{47}$ el-Awaisi, 1986, p. 44.

${ }^{48}$ Israel Gershoni, The Muslim Brothers and the Arab Revolt in Palestine, 1936-39, Middle Eastern Studies, Vol. 22, 1986, No. 3: 367-397, p. 379.

${ }^{49}$ Thomas Mayer, Egypt and the 1936 Arab Revolt in Palestine. Journal of Contemporary History, Vol. 19, 1984, No. 2:275-287, p. 278.

${ }^{50}$ Măhmoud Abdel Halim, al-lkhwan al-Muslimoun. Ahdath Sanaat al-Tarikh. Vol. 1. 1928-1948. 4th edition (Alexandria: Dar al-Dawaa, 1994), p. 88.

${ }^{51}$ Cited in Adnan M Rizk, Mustafa al-Sibai 1915-1964 (Damascus: Dar al-Qalm, 2000), p 110.

52Mayer, 1984, 284.

${ }^{53}$ Awatef Abdel Rahman, Misr wa Filistin (Cairo: Dar Al Maarefa, 1980), p. 68.
} 


\begin{tabular}{|lcc|}
\hline CBJM 1360009 & \multirow{2}{*}{ Initial } & CE: ER QA: XX \\
2 August 2017 & Coll:XX & QC:XX \\
\hline
\end{tabular}

number of Cairo mosques, the movement used the periodical al-Nadhir ${ }^{54}$ to launch a series of articles about Palestine. Members also distributed several pamphlets in cafés and public offices, and called for the boycott of Jewish shops in Cairo. The pamphlets contained a list of such shops with a warning that, 'every piaster paid to these shops goes to Jews in Palestine to buy weapons to use for killing Muslim brethren in Palestine, ${ }^{55} \mathrm{Al}$-Banna used to send his followers to mosques on Fridays to inform Muslims about the plight of the Palestinians and to collect donations. One veteran Brother, for instance, went to a mosque in Cairo frequented by the upper class, and, after Friday prayers, he started preaching about Palestine, raising a copy of the Qur'an in his hand and saying that, 'Brothers in Palestine are being killed because of this holy book, and the Jews and British troops force themselves into [Palestinian] houses, tear apart that book and stamp on it with their feet'.56

The Palestine issue was a recurrent theme in all the Brotherhood publications. The Brothers occasionally served as peripatetic preachers in mosques to warn Muslims against the'Jewish threat' and profiled the movement as the protector of Arab and Islamic land; in so doing, the Brotherhood Islamized the Palestine question by reducing it to an inevitable tension between the Jews and Muslims, instead of tackling the political roots of the conflict. Al-Nadhir published a series of articles by Mahmoud Saleh entitled The Danger of Jews and the threat they posed to the Islamic world; each episode detailed the'plot' woven by the Jews against Islam. Saleh claimed that the so-called Jewish plot began with Freemasonry, which had incited rebellion across Europe, followed by the Marxist ideology, which reiterated the call for rebellion. He also accused the Jews of controlling the fields of 'intelligence, brokering, arms sales, and media'. There was a tendency to label Jews as enemies of Islam, and according to Brother Saleh Ashmawy, Jews were the historic enemies of Muslims who still carried that hatred. ${ }^{57}$

al-Nadhir's editorials expressed similar sentiments, and one of them condemned the appointment of an Egyptian Jew to serve as Egypt's Consul in Paris:

The Egyptian Muslim and Arab government has appointed a new Egyptian consul in Paris, and he is a Jew. This is a dubious choice. The number of Egyptian Jews is no more than 22,000, so how would any of them represent an Islamic country of millions of people? The Consul represents the country and its laws and regulations [including] marriage and divorce, and as the king's deputy, receives information on state affairs and commercial and economic matters regarding our trade with the outside world; because this Jew has no fatherland and no nationality, appointing him as Consul is like appointing a spy in the ministry of foreign affairs. We ask the ministry to justify the selection, when it could have chosen an Egyptian [Muslim] man who could be more suited and more qualified for the job. The Muslim ministry should know about people's rumours regarding Yousef Qattawi Pasha, a Jew and head of the Egyptian Chamber of Commerce, who might have had a say in this selection; as if it were not enough that Jews control internal affairs, now we give them the right to represent us abroad, too. ${ }^{58}$

Another of al-Nadhir's editorials ${ }^{59}$ penned by al-Banna described how the MB's headquarters had been raided by the police searching for, and confiscating, hundreds of copies of a booklet

\footnotetext{
${ }^{54}$ The magazine was launched on 30 May 1938, marking the tenth anniversary of the movement. It ceased on 16 October 1939.

${ }^{55}$ Abdel Halim, 1994, 174.

${ }^{56}$ Abdel Halim, 1994, 91

${ }^{57}$ Al-Ikhwan al-Muslimun, 27 June 1946.

${ }^{58} \mathrm{Al}-\mathrm{Nadhir}$, issue 14, 28 August, 1938.

${ }^{59} \mathrm{Al}-$ Nadhir issue 9, 24 July, 1938.
} 


\begin{tabular}{|c|c|c|}
\hline $\begin{array}{l}\text { CBJM } 1360009 \\
2 \text { August } 2017\end{array}$ & Initial & CE: ER QA: XX \\
\hline
\end{tabular}

entitled Fire and Destruction in Palestine. This was an 80-page booklet, produced by the Higher Arab Committee in Palestine, containing more than 50 gruesome images of people being tortured, and depicting British soldiers allegedly tearing up copies of the Qur'an. The booklets had been sent to the Brotherhood for distribution across Egypt, and the MB had managed to circulate thousands of copies across the country, leaving only a few hundred copies in their headquarters. Al-Banna proudly admitted to the possession of the booklets, and even gave himself up to the police, but no charges were brought against him. 'The Ikhwan went many times before the prosecution and offered themselves for interrogation and even imprisonment, but the prosecution service, God forgive them, refused our appeal [...] this time

10 we'll ask them to either charge us, if we have committed a crime, or return the booklets to us', he wrote in the editorial.

The Brotherhood employed a variety of tactics to associate their movement with the Palestine issue in addition to the articles published about the 'Jewish threat' and the circulation of pamphlets. It used the mosques to urge Muslims to support the Palestiniancause

15 and to spread the call to boycott Jewish stores in Cairo; it arranged demonstrations across Egyptian cities and provinces, such as those marking the anniversary of the Balfour Declaration in November 1938, and co-founded the Delta Committee in 1947 to collect donations to arm the Palestinians. Donations had been collected for the Palestinian cause since the mid-1930s, although one senior member admitted that the money was no longer meant to'help our jihadi Palestinian Brethren, because they did not need such help; wealthy Palestinian merchants already supported those jihadists'; instead, he said, the donations were to be spent 'on dawa matters'. ${ }^{0}$ The Palestinian issue, like the missionary one, nonetheless provided an unparalleled opportunity for the Brotherhood to mark its morality politics, calling for an immediate urge to right a wrong, not by offering new policy ideas but by demonstrating the moral position of speakers.

Al-Banna attended a conference in Cairo in 1946 to discuss the end of Jewish migration to Palestine, and delivered a speech in Arabic that was rather contradictory: on the one hand, he said that he did not oppose the Jews' migration owing to religious reasons because the Qur'an called for co-existence, citing the Qur'anic verse (29:46), 'And dispute you not with

30 the People of the Book', and on the other hand, he said that the Qur'an warned against the Jewish threat from an economic and legal perspective, citing another verse (4:160-161), 'For wrongdoing on the part of the Jews, We made unlawful for them [certain] good foods which had been lawful to them, and for their averting from the way of Allah many [people]. That they took usury, though they were forbidden; and their consuming of the people's wealth

35 unjustly; we have prepared for those among them who reject faith a grievous punishment.'.

The same trend continued within the MB following al-Banna's death, and the Palestinian question was regarded as one episode of an ongoing religious battle between Muslims and Jews, 'The Palestinian issue is the primary one for Islam and for Muslims, and the weak battle

40 that took place four years ago [1948] was just the start of a greater battle in which all forces in the world will be allied against Islam; after the age of narrow-minded nationalism and scattered issues that divided the nation, Muslims needed one issue to unite their efforts [...] which could reveal their many enemies [...] and more importantly, Muslims needed a front

${ }^{60}$ Abdel Halim, 1994, 174.

${ }^{61}$ Abdel Halim, 1994. 


\begin{tabular}{|lcc|}
\hline CBJM 1360009 & \multirow{2}{*}{ Initial } & CE: ER \\
2 August 2017 & Coll:XX & QC:XX \\
\hline
\end{tabular}

to remind them of their fighting nature since the Saladin days, after a [long] period of humiliation, unprecedented in history', warned al-Muslimun editorial published in November 1952. Said Ramadan, al-Banna's son-in-law, launched al-Muslimun magazine in Cairo in March 1951, where it continued until 1954, after which it moved to Damascus when Ramadan fled Egypt, and later moved with him to Switzerland in $1961 .{ }^{62}$ The magazine featured several articles attacking the Jews as enemies of Islam; for instance, the Azharite, Mohamad Abu Zahra, explained that the Qur'an dedicated a large part of its content to talking about Jews, in his series about them and the Qur'an, 'because the Jews', he wrote,'never wanted any good for Islam, and their view of themselves as the "chosen people" was "the work of Satan".63

A new genre of prison literature had also emerged in the post-Six Day War period, in addition to the MB's publications and the General Guides' memoirs. ${ }^{64}$ The expansion of Islamic publishing resulted in print editions of biographies and other popular history books such as prison memoirs and al-Banna's biography being sold in Egypt and across the region; the books were 'often sold expensively in Saudi Arabia, and the profits were used to subsidise

15 cheap editions' in Egypt, making those'previously banned from any form of participation in public life' becoming involved in historiography ${ }^{65}$ The majority of those memoirs did not engage in critical analysis of the movement's history, but focused primarily on the murder of al-Banna, which many saw as part of an 'ongoing conspiracy against Islam'; the style 'was Islamic, in the sense that more than a few stylistic similarities existed between the exemplary life of al-Banna and the sira [biography] of the prophet Muhammad', while lacking any substantiated evidence such as academic references. ${ }^{66}$ One example was the memoirs of Zaynab al-Ghazaly, who led the Muslim Sisterhood section and was imprisoned under Nasser's rule; in her memoirs, she claimed that angels surrounded her in her cell to protect her from her captors. ${ }^{67}$

The campaign against Nasser has remarkably continued, with numerous memoirs of senior Brothers who were imprisoned during his era, accusing him of scorning and rejecting Islam. The former General Guide, Hamed Abu Nasr, ${ }^{68}$ accused Nasser of being unreligious and not having 'ever tasted Islam or any other religion'. Nasser was accused of idolizing Kemal Atatūrk, who had secularized Turkey, and also blamed for'destroy[ing] the Arabic language'

30 because he had adopted the vernacular in his speeches. This is far from true, however; the late intellectual Fouad Zakariyya argues that the Nasserite era (1952-1970) witnessed the establishment of new/slamic institutions and that 'the Islamic doctrine was highly revered in the domains of general education, media, and official addresses.' The confrontation between Nasser and the MB was one reason behind the depiction of the Nasserite regime as non-Islamic, argues Zakariyya. ${ }^{69}$

\footnotetext{
${ }^{62}$ Mohammad Fathi Ali Shoeir, wasa'il al-Ilam al-Matbua fi dawat al-ikhwan al-Muslimin. Unpublished MA thesis, Al-Imam University, Saudi Arabia, 1983, p. 325.

${ }^{63}$ Al-Muslimun, January 1954.

${ }^{64}$ Kupferschmidt, 2008, 183.

${ }^{65}$ Yoav Di-Capua, Gatekeepers of the Arab Past (Berkeley: University of California Press, 2009), p. 314.

${ }^{66}$ Di-Capua, 2009, 317

${ }^{67}$ Zeinab Al-Ghazaly, Ayyam min Hayati (Cairo: Islamic Publication and Distribution, 1999).

${ }^{68}$ Hamed Abu Nasr (1987).

${ }^{69}$ Fouad Zakariyya, Myth and Reality in the Counterparty Islamist Movement (London: Pluto Press, 2005), pp. $20-21$.
} 


\begin{tabular}{|c|c|c|}
\hline $\begin{array}{l}\text { CBJM } 1360009 \\
2 \text { August } 2017\end{array}$ & Initial & $\begin{array}{ll}\text { CE: ER } & \text { QA: XX } \\
\text { Coll:XX } & \text { QC:XX }\end{array}$ \\
\hline
\end{tabular}

\section{Jihad against the Jews}

The decade of the 1970s provides an important watershed moment in the history of the Brotherhood in Egypt, with Sadat's encouragement for such movements to thrive. The MB society in fact benefited from several political opportunities as well as resources: the latter were reflected in the financial support it received from the Gulf States, particularly Saudi Arabia, while the former included openings in the political sphere such as Sadat's release of MB members in the early stages of his rule. It was during that period that the Brotherhood managed to re-launch its al-Dawa magazine reflecting the group's ideology. Sadat, moreover, raised the slogan 'State of Religion and Science' and referred to the 1973 war as the'10th of

10 Ramadan War', fought with the slogan 'Allah is Great'. The conflict with Israel was then framed as jihad and as a continuation of the Prophet's battles against the Jews, a concept reinforced in the MB's printed media at that time.

Al-Dawa magazine, for one, focused on warning against four main enemies: Jewry, Crusaders, communism and secularism. ${ }^{70}$ The children's corner even contained articles aimed at indoctrinating the young generation on the hatred of Jews, 'Muslim lion cub, annihilate their [the Jews] existence, those who seek to subjugate all humanity so as to force it [humanity] to serve their satanic designs', said one article. ${ }^{71}$ Jews were then depicted as a race 'corrupt at its roots, full of duplicity, and the Muslims have everything to lose in seeking to deal with them: they must be exterminated.72 The Brothers were therefore vehemently against the Egyptian-Israeli peace treaty, and dedicated several articles and editorials to justify their stance.

The Brotherhood launched a relentless campaign in al-Dawa against communism, seeing it as an extension of the anti-Muslim Russian and Zionist plot, which culminated in the 1967 defeat by Israel, ${ }^{73}[C]$ ommunism was born out of Judaism. Its principles, leaders and revolution were Jewish Zionists, and the establishment of the State of Israel, from the Euphrates to the Nile, was one main goal of the communist strategy', but, according to the articles, the plot also involved the U.S.A. whose aim was to eradicate Islam and usurp the Muslims' wealth. ${ }^{74}$ The Russians and the U.S.A., claimed al-Dawa, 75 supported the Jews during the 1948 war. Al-Dawa magazine issued several warnings against normalizing relations with Israel or buying Israeli products. ${ }^{76}$ Jews were even dehumanized, 'Even if they [Jews] try hard, they cannot be [like other humans] because this is how they were created', arguing that Jews simply hated Christianity as much as they hated islam and that 'they want to rule the world as God's chosen people.?7

What is noteworthy in the MB media output is the movement's persistent attempts to re-write history by glorifying its role in the 1948 war against Israel (which ended in defeat), as an example of sacrificial jihad, while magnifying the impact of the 1967 defeat as divine justice on Nasser's regime for its crackdown on the Islamists. The MB media meanwhile hardly

\footnotetext{
${ }^{70}$ Gilles Kepel, Muslim Extremism in Egypt. The Prophet and Pharaoh (Berkeley: The University of California Press, 1984), p. 111.

${ }^{71}$ Cited in Kepel, 1984, 112; see also Liwa al-Islam, November 1990.

${ }^{72}$ Kepel, 1984, 112.

${ }^{73}$ Scholars such as Tariq al-Bishri also believed that the Jewish leaders of the Communist movement in Egypt in the 1940s were close to the Zionist movement in Israel, which they supported in 1948. The aim of the Communist movement, according to al-Bishri (2002, p. 23), was to counteract the Islamic movement led by Islamic associations such as the MB and Young Egypt party; nevertheless, the Communist movement managed to attract a sector of the youth and enrich the political sphere at the time, argues al-Bishri.

${ }^{74}$ Al-Dawa, June 1977.

${ }^{75}$ Al-Dawa (July 1978).

${ }^{76}$ For example, al-Dawa, Sept. 1979.

${ }^{77}$ Al-Dawa, Oct 1979.
} 


\begin{tabular}{|c|c|c|}
\hline $\begin{array}{l}\text { CBJM } 1360009 \\
2 \text { August } 2017\end{array}$ & Initial & $\begin{array}{ll}\text { CE: ER } & \text { QA: XX } \\
\text { Coll:XX } & \text { QC:XX } \\
\end{array}$ \\
\hline
\end{tabular}

published material about the impact of the 1973 war, save for its subsequent peace treaty, although this war was, and has been, exalted as an example of Egyptian heroism; in fact, former Egyptian military rulers excelled in constructing the narrative of the 1973 war as a sweeping victory for the Egyptian army, with Sadat as the 'Leader of War and Peace', and Mubarak as the initiator of 'the first air strike against Israel', miraculously leading to Egypt's victory. This narrative has been reflected in the curricula of schools and universities. ${ }^{78}$

The Palestine question has remained an Islamic issue for the MB, asserted by the former Supreme Guide, Hamid Abu Nasr in 1988, in an open letter to the kings, presidents and emirs of Arab countries, 'We Muslim Brothers believe that the Palestinian issue is an Islamic issue par excellence, and its responsibility is incumbent upon each Muslim, whether ruler or ruled, because it is part of our creed and the pulse of our hearts, before being a piece of land usurped by occupiers. The Islamic and historical facts confirm every day that the Zionists have nothing but hatred and deception for us and all humanity [...]. The Palestinian people have chosen their path and continue with their intifada [...] and Arabs and all Muslims now

15 bear their historical responsibility in supporting this blessed intifada ${ }^{\prime 79}$ Celebrating the third anniversary of the Palestinian intifada, Liwa al-Islam magazine reiterated the Brotherhood's support for the intifada, 'the Palestine issue, as the Muslim Brothers understand it, is an Islamic issue and not an issue of one people, it is the issue of all Muslims [...]; depriving the issue of its Islamic character does not serve anyone but the enemies of Palestine.'80

Zionism was an extension of the Crusades, argued Mohamed al-Ghazaly, a former Brother whose writings were regularly published in the movement's outlets, II was surprised to read Ronald Reagan's words when he was at Windsor Palace, during his recent visit to Britain; he said [...] that it was from that palace that the Crusades began to spread the Judeo-Christian values [...]. The new crusades are led by men drawing on [the concept of the ancient] Crusades with Zionism. [These modern crusades] began with Lord Balfour in the U.K. and have ended with presidents of the U.S.A. in recent years. ${ }^{\prime 1}$ The Brotherhood media discourse, whether magazines, prison tales or memoirs, consequently provided a tool for rearranging the past and contesting mainstream discourses.

The 1990s and 2000s also saw the proliferation of Islamic satellite channels, mostly funded by the Salafists and the $M B, 82$ not to mention the new outreach opportunities opened up on the Internet. The MB experimented with the new Internet technology in 1998 to host its al-Dawa magazine in a new format such as www.aldaawah.org, registered through a company located in Chicago, U.S.A. and al-Shahed (https://ashahed2000.tripod.com). ${ }^{83}$ The sites focused heavily on the Palestinian issue, confirming that the Brotherhood would never acknowledge the State of Israel. ${ }^{84}$

\footnotetext{
${ }^{78}$ Mellor, 2016, 136.

${ }^{79}$ Liwa al-Islam, June 1988.

${ }^{80}$ Liwa al-Islam December 1989

${ }^{81}$ Liwa al-Islam, November 1990

${ }^{82}$ Hosam Tammam, al-Fada'iyyat al-salafiyya. Hal tuqawem al-salafiyya almanat al-fada'iyyat lil tadiyon? Islamyun web forum, 18 May 2009, https://www.islamun.net (accessed on 22 April 2016).

${ }^{83} \mathrm{Al}$-Amira Samah Farag Abdel Fattah, al-ilam al-gadid. Ro'ya min waqi al-solekiyat al-itisaliya li shabab gamaat al-ikhwan al-muslimin. unpublished manuscript, 2012, https://scholar.cu.edu.eg/?q=mediatizedconflict/node/43160 (accessed on 18 November 2016). Some archived pages can be viewed using WayBackMachine available on https://web.archive.org

${ }^{84}$ The Palestinian activist Ibrahim Allosh posted a comment on ashahed2000 website, responding to an article by Jonathan Freedland in the Guardian, published on 17 October 2001. Freedland questioned the rationale behind the Arabs' obsession with the Palestinian cause, and how the Israeli withdrawal of forces from Gaza could ever change the lives of Arabs and Muslims anywhere else in the region: 'of course Mr Freedland was deliberately ignoring the bonds between Arabs and Muslims, cultural and national bonds, or Arabism and Islam', wrote Allosh.
} 


\begin{tabular}{|c|c|c|}
\hline $\begin{array}{l}\text { CBJM } 1360009 \\
2 \text { August } 2017\end{array}$ & Initial & CE: ER QA: XX \\
\hline
\end{tabular}

The former Mubarak regime attempted to win the support of Islamists and appease their demands by controlling religious discourses at school. These groups resisted the attempts by providing an alternative dialogue, including a school system, while infiltrating state institutions such as Al-Azhar, on the grounds that the society suffered religious ignorance, moral decadence and the loss of its Islamic identity at the hands of despotic regimes.$^{85}$ This explains the upsurge in the number of those applying for a discipline related to Islamic studies during the period 1995-2006: the number of students enrolled to study Qur'anic and Islamic courses constituted approximately 20 per cent of the total number of students enrolled in Humanities and Social Sciences in 2005-2006, or about 164,292 students. ${ }^{86}$

The MB won a massive 88 seats in the 2005 parliamentary elections, as a result of which they called for the support of resistance movements everywhere in Palestine, Iraq and the Golan Heights, the backing of boycott movements, and redrawing 'Arab-US-Zionist' relations. A report, detailing the Mb's achievements between 2005 and 2009, ${ }^{87}$ condemned the government's lack of response to the Israeli film 'Closed Zone', which/according to the MB, tarnished Egypt's image and violated its sovereignty, because it implied that Egypt was behind the siege on Gaza, when it refused to allow a Palestinian child to pass through the Rafah Crossing. The MB declared its intention to reconsider international treaties in its manifesto for the Shura Council by-elections in 2010, particularly Camp David, and to emphasize the legitimacy for resistance as an Islamic duty against the 'Zionist enemy' calling for any attempt to normalize relations with Israel.

The 'religionization' of political conflicts was not confined to the Palestine issue; the MB used the same discourse when tackling other regional crises such as the Iraq War (2003) and the recent Arab uprisings. It depicted Western countries and Israel as an alliance of plotters against the Islamic nations. Following the Arab uprisings, for instance, IkhwanOnline (the Arabic portal) repeated its warnings about the grand scheme against the Arabs and Muslims, singling out Professor Bernard Lewis as the mastermind of the new one:

Those who have not read history [books] think that what America did to Iraq-from occupation and division - was an impulsive action and a by-product of recent events [...] but the great truth which they forget is that what is happening now is the enactment of the imperialist plot planned, articulated and publicized by global Zionism to divide the Islamic world and turn it into a 'paper mosaic' in which the Zionist entity [Israel] could rule [...]. When we publish this dangerous document by Bernard Lewis, we aim to raise Muslims' awareness of the plot, particularly that of the youth [...] who have been subjected to the biggest brainwashing process in history by those working hard in the service of the Zionist-American project, and who ridicule such plans as a 'conspiracy theory', despite what we saw before with our own eyes in Palestine, Iraq, Sudan and Afghanistan. ${ }^{88}$

Bernard Lewis was then introduced as the 'Zionist Orientalist', and the allegation seems to have been drawn from different sources, including Oded Yonan's document attributing all of them to Lewis; however, it is noteworthy that this particular allegation has also been circulating in mainstream media. ${ }^{89}$

\footnotetext{
${ }^{85}$ Sebnem Gumuscu, 'Class, status, and party: the changing face of political Islam in Turkey and Egypt', Comparative Political Studies, 43(7), 2010: 835-861.

${ }^{86}$ OECD, Reviews of National Policies for Education Higher Education in Egypt (Paris: OECD Publishing, 2010), p. 190.

${ }^{87}$ https://www.ikhwanwiki.com/index.php?title=\%D8\%A7\%D9\%84\%D8\%A5\%D8\%AE\%D9\%88\%D8\%A7\%D9\%86_\%D9\% 88\%D8\%A7\%D9\%84\%D8\%A8\%D8\%B1\%D9\%84\%D9\%85\%D8\%A7\%D9\%86.pdf

${ }^{88}$ Fathi Shihab Eddin, mokhattat Bernard Lewis li tafteet al-alam al-islami. IkhwanOnline, 9 Jan. 2011, https://www.ikhwanonline.com/new/Article.aspx?SecID=344\&ArtID=77565

${ }^{89} \mathrm{See}$, for instance, Abdel Rahim Ali's interview on Ala Hawa Misr talk-show, An-Nahar station, dated 29 November 2016.
} 


\begin{tabular}{|c|c|c|}
\hline $\begin{array}{l}\text { CBJM } 1360009 \\
2 \text { August } 2017\end{array}$ & Initial & $\begin{array}{ll}\text { CE: ER } & \text { QA: XX } \\
\text { Coll:XX } & \text { QC:XX } \\
\end{array}$ \\
\hline
\end{tabular}

During the MB rule (2012-2013), it released al-Horriya wal adala or Freedom and Justice newspaper as the voice of their Freedom and Justice Party. The front page of the first print edition of the newspaper, published on 20 October $2011,{ }^{90}$ featured a statement by a Hamas leader claiming that Mubarak had asked Hamas to free Shalit (the alleged Israeli spy) 'for nothing in return' and the obsession with Israeli-Egyptian relations continued in later issues. The Israelis were claimed to be irked by the Arab Spring, according to a survey that ranked it as the first concern for them, followed by nuclear weapons. ${ }^{91}$ There were also allegations that the 'Zionists have allocated one million dollars to anyone killing al-Qarni', referring to the Saudi cleric, Ayad al-Qarni, allegedly one of the MB's supporters in Saudi Arabia. ${ }^{92}$ There were also warnings that the 'Arab absence' from Central Asia had 'allowed the Zionist and American lobby to extend its influence in the region,, 93 and a further warning against the Zionist-American plan to divide Iraq by creating an Iraqi federation..$^{94}$

During Morsi's rule, however, the tone towards Israel became conciliatory, as illustrated in the letter sent by Morsi to the late Shimon Peres. Mohamad Habib, former Deputy General

15 Guide, reprinted Morsi's letter, which was leaked to Israeli media, including warm words such as, 'Being desirous of maintaining and strengthening the cordial relations which so happily exist between our two countries' and '[We] express to Your Excellency our sincere wishes for your happiness and for the prosperity of your country. ${ }^{\prime 5}$ Habib harshly condemned the letter, expressing his deep regret that an MB leader could address an Israeli official in such a conciliatory style. This was indeed a radical turn for the MB leadership, especially if compared with their stance towards the former Israeli president Navon's visit to Egypt on 26 October 1980. The then General Guide Umar Tilmisani wrote that the day of Navon's visit was 'one of the saddest days on plighted peoples [...] the day when he who is the most aggressive [person] towards the believers, has set foot in this pure land. People of Egypt were surrounded by silent sadness when they saw their army officers saluting the representative of the butchers behind [the massacre of] Deir Yassin, and those who usurped Muslim lands. ${ }^{96}$

The MB resumed its campaign against 'Zionism and Crusaders', following the overthrow of Morsi in 2013, and in 2015, Ikhwan's website, Egypt Window, published an article dated 30 May 2015 entitled 'The Western Stance Toward the Brotherhood' in which it argues that 30 the events facing the whole region were part of a calculated plot against Islam, which the good [Muslims] ought to win in the end, and the MB has assigned itself the role of the caller to awaken those Muslims in their long jihad against the enemies. To support its allegations, the MB usually published materials that tended to rely heavily on extracts from the Qur'an and Hadith, and there is indeed an 'extensive resort to Qur'anic exegeses' in order to demon-

35 strate the depravity of the Jews and the roots of their enmity to Islam, and to show that the present conflict is the direct continuation of the struggle the Jews waged against the Prophet. ${ }^{\prime 7}$ Seen in this context, the Palestinian issue was a problem concerning an Islamic endowment (waqf) which the early Caliphs refused to divide, leaving it as a bequest to the entire Islamic world. ${ }^{98}$

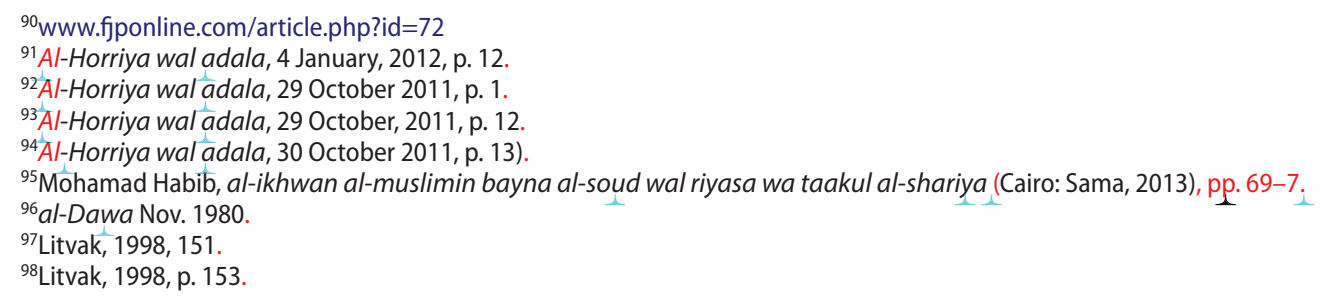




\begin{tabular}{|c|c|c|}
\hline $\begin{array}{l}\text { CBJM } 1360009 \\
2 \text { August } 2017\end{array}$ & Initial & $\begin{array}{ll}\text { CE: ER } & \text { QA: XX } \\
\text { Coll:XX } & \text { QC:XX }\end{array}$ \\
\hline
\end{tabular}

\section{Conclusion}

The Brotherhood's hostility towards Israel featured heavily in the MB media discourse with regard to the Palestine question as an Islamic issue. The movement's stance towards peace treaties with Israel oscillates, nonetheless, between acceptance and rejection, depending on its current political power. The MB's stance towards jihad similarly swings between accepting violence in the name of Islam (in the cases of Afghanistan, Hamas and Hezbollah) and rejecting it at other times (al-Qaeda).

The MB's Islamization of the conflict was generally part of the movement's efforts to propagate a global transnational movement and, hence, its interest in regional conflicts and the reluctance to support territorial nationalism in either Egypt or Palestine. It regarded instead the Islamic nations as part of a global Umma. The movement also considered the 1967 defeat as a historical lesson to Arab rulers who adopted Western concepts such as socialism or nationalism. This did not mean, however, that rising Islamism was triggered solely by the Arab defeat in 1967; rather, it reflects the shift in the political process, with each ruler of Egypt drawing on religious discourse to garner public support for his policies. ${ }^{99}$ Hamas, founded in 1987 as 'the underground wing of the Muslim Brethren movement in the Gaza Strip', similarly propagated a religious perception of the conflict by competing with 'the secular national Palestinian forces within the PLO, and in order to refute Zionist-Israeli claims to the land.' ${ }^{100}$ Hamas, for instance, compared the Palestinians to early Meccan Muslims who had to migrate to Medina with the Prophet because of their religious beliefs. ${ }^{101}$

If the Islamic discourse seems to have gained a strong foothold since the $1967 \mathrm{war}$, this has been largely due to the proliferation and hegemony of that discourse in mainstream media as well; both have deployed Islam as a political instrument while naturalizing religious discourse to fulfil the utilitarian duties of the state. ${ }^{102}$ This shows the powerful influence that religion has on political conflicts. ${ }^{103}$ Islamist discourse, like that adopted by the MB, imposes a certain religious understanding as the only truth while accusing anyone who challenges this understanding as opposing God's will. ${ }^{104}$ Political conflicts are consequently transformed into religious conflicts and a zero-sum game, with dwindling chances of ever being resolved through political debates.

\section{Disclosure statement}

No potential conflict of interest was reported by the author.

\footnotetext{
${ }^{99}$ Conversely, the past decade has witnessed an intensification of the debate surrounding 'atheism' as a potential response to the rise of jihadist violence, such as that of ISIS (see, e.g., Fi Falak al-Mamnou programme on France 24 Arabic, 11 Nov. 2016).

${ }^{100}$ Litvak, 1998, 149

${ }^{101}$ Litvak, 1998, 157

${ }^{102}$ Gregory Starrett, Putting Islam to Work: Education, Politics, and Religious Transformation in Egypt (Berkeley: University of California Press, 1998), pp. 8-9.

${ }^{103}$ See also Claudia De Martino, Israeli War Perception from the Six Days War to the Operation Cast Lead: An Analysis of the Israeli Siege-Mentality. International Journal of Euro-Mediterranean Studies, Vol. 2(2), 2009: 235-252, p. 236.

${ }^{104}$ Abu Zeid, 1994.
} 